\title{
Non-Cutaneous Melanoma
}

National Cancer Institute

\section{Source}

National Cancer Institute. Non-Cutaneous Melanoma. NCI Thesaurus. Code C8711.

Melanoma is a malignant tumor of melanocytes, cells that are derived from the neural crest. Although most melanomas arise in the skin, they also may arise from mucosal surfaces or at other sites to which neural crest cells migrate. (PDQ) 